\title{
КАТЕГОРІЯ ВІДМІНКА В АСПЕКТІ АКСІОЛОГІЧНОЇ ПРАГМАЛІНГВІСТИКИ
}

\author{
ОКСАНА ХАЛІМАН \\ Національний фармацевтичний університет, Харків - Україна \\ KATEGORIA PRZYPADKA \\ W ASPEKCIE PRAGMALINGWISTYKI AKSJOLOGICZNEJ
}

\begin{abstract}
OKSANA CHALIMAN
Narodowy Uniwersytet Farmaceutyczny w Charkowie, Charków - Ukraina

STRESZCZENIE. W artykule scharakteryzowano możliwości znaczenia gramatycznego (ZG) przypadka jako morfologicznego środka wyrażania oceny we współczesnym języku ukraińskim.
\end{abstract}

\section{THE CATEGORY OF CASE \\ IN THE VIEW OF AXIOLOGICAL PRAGMALINGUISTICS}

\author{
OKSANA KHALIMAN \\ National Pharmaceutical University, Kharkiv — Ukraine
}

ABSTRACT. The article deals with the characteristics of the grammatical meaning of case as a morphological means of expressing evaluation in modern Ukrainian.

$\mathrm{H}$ а сучасному етапі розвитку лінгвістики в аспекті комунікативнопрагматичних досліджень особливий інтерес мовознавців викликає категорія оцінки. При цьому увагу сфокусовано на вивченні особливостей ціннісної картини світу носіїв мови та вербалізації оцінки з огляду на оцінний потенціал мовних одиниць.

Сутність лінгвофілософської категорії оцінки та характер іï мовної презентації активно вивчали вітчизняні й зарубіжні мовознавці. Дослідження вчених стосувалися особливостей вираження оцінки одиницями різних мовних рівнів (лексико-семантичного - Т. Вільчинська, В. Іващенко, Т. Космеда, Н. Левадна, Ф. Моісеєнко, В. Труб, словотвірного - І. Ковалик, Т. Космеда, Л. Летюча, В. Лопатін, А. Нелюба, О. Олексенко, Л. Родніна, Т. Черторизька, В. Шинкарук, Л. Шутак, фразеологічного - В. Ужченко, Л. Авксентьев, А. Івченко, Н. Грозян, Т. Космеда, С. Олійник, специфіки частиномовного розшарування лексики з оцінною семантикою - Т. Денисюк, О. Жижома, I. Кононенко, Т. Космеда, Н. Левадна, Л. Мацько, Г. Монастирецька, О. Наконечна, С. Равлюк, Г. Серпутько, С. Педченко, В. Ткачук та відповідних синтаксичних конструкцій - В. Мараховська, М. Ретунська, О. Семенюк, П. Ткач, С. Шабат, І. Шкіцька), оцінки як текстової (дискурсивної) категорії (О. Вольф, Т. Космеда, молоді науковці М. Кайки, М. Михальченко) в дискурсах різного функційного призначення, напр., художньому - У. Соловій, епістолярному - Н. Павлик, публіцистичному - Л. Гусліста, Н. Кочукова, С. Равлюк, І. Онищенко, науковому Ж. Краснобаєва-Чорна, політичному - К. Серажим, рекламному - В. Зірка, Ю. Булик, розмовному мовленні - В. Труб; концептів як репрезентантів аксіо- 
логічної інформації (Т. Вільчинська, Т. Космеда, Н. Плотнікова, А. Приходько, Ю. Шамраєва) та ін. Функційно-прагматична спрямованість сучасних лінгвістичних досліджень відкрила можливості для вивчення нових аспектів категорії оцінки. Аналіз функційної специфіки граматичних одиниць дав змогу мовознавцям закцентувати увагу на їх прагматичній значущості в комунікативному процесі. Спираючись на засади лінгвістичного функціоналізму, що є основою граматики активного типу (праці В. Виноградова, Л. Щерби, Р. Якобсона, О. Бондарка, Ф. Бацевича, І. Вихованця, К. Городенської, Н. Гуйванюк, Г. Золотової, А. Загнітка, Т. Космеди, О. Кубрякової, О. Ремчукової та ін.), вчені почали досліджувати граматичні одиниці і як засоби вираження оцінки, співвідносячи їх структурні особливості з комунікативним процесом. Ці дослідження мотивують необхідність розробки „Граматики оцінки” - всебічного аналізу системи граматичних засобів вираження оцінних значень з урахуванням їхніх прагматичних характеристик. Як відповідний крок до створення такого комплексного опису авторкою цієї статті вже було схарактеризовано граматичні значення роду й числа як продуктивні засоби вираження оцінки в сучасній українській мові1.

Мета цієї наукової розвідки - 3'ясувати й схарактеризувати можливості граматичного значення відмінка як морфологічного засобу вираження оцінки в сучасній українській мові.

Предмет, названий іменником, виявляє себе не лише через свої внутрішні якісні та кількісні ознаки, а й через зовнішні, коли він вступає у відношення 3 іншими фактами довкілля, що знаходить своє узагальнене відображення в граматичних фактах мови, зв'язках назви предмета з іншими словами, що реалізується певним оформленням слова. Оформлення назви предмета залежить від характеру виражених відношень, що „стають змістом граматичної категорії відмінка" - граматичної словозмінної категорії імені, що виражає його синтаксичне відношення до інших слів у словосполученні чи реченні. Зовнішніх відношень між фактами довкілля значно більше, ніж внутрішніх, тому граматичне значення в межах граматичної категорії відмінка виявляється більш виразно, ніж граматичне значення в межах інших граматичних категорій. Крім того, кожне граматичне значення відмінка (кожний відмінок) має кілька часткових значень, чим відрізняється від граматичних значень інших граматичних категорій, що, як правило, однозначні ${ }^{3}$.

Відносячи відмінок до граматичних категорій, оцінний потенціал яких мінімальний, В. Лопатін усе ж виділяє оцінну функцію, характерну для родового партитивного, що вказує на високу інтенсивність ознаки чи ії повну відсутність, порівн. (рос.): Народу-то; Билетов - ни одного ${ }^{4}$ (аналогічно в перекладі укр.: Народу-то; Квитків - жодного).

Така обмеженість у можливостях вираження оцінних значень зумовлена специфікою категорії відмінка, про що пише, наприклад, О. Безпояско: на відміну від категорійних парадигм особи, часу, способу, стану, частково роду та ін., в яких граматичні форми - носії сем, об'єднані родовим категорійним значенням, що є інваріантом кожної семи, „кожен відмінковий афікс протиставлений усім іншим тільки формально".

${ }^{1}$ О. В. Халіман, Морфологічні засоби вираження категорії оцінки в сучасній украйнській мові: рід $і$ число, автореф. дис. канд. філол. наук, Харків 2011.

${ }^{2}$ М. В. Леонова, Сучасна українська літературна мова. Морфологія, Київ 1983, с. 52-53.

${ }^{3}$ Там само, с. 53.

${ }^{4}$ В. В. Лопатин, Оиенка как объект граматики, [в:] Русский язык: проблемы грамматической семантики и оченочные факторы в языке, Виноградовские чтения, Москва 1992, с. 72.

${ }^{5}$ О. К. Безпояско, Граматика украӥнської мови. Морфологія, Київ 1993, с. 9. 
Відмінкові форми іменника слугують в українській мові для вираження різних значень - кожна відмінкова форма є носієм таких сем, що не інтегруються в єдину категорію. Але, разом із тим, кожна відмінкова сема зараховує всі відмінкові форми іменника до єдиного категорійного значення предметності, кожна відмінкова форма прикметника - до єдиного категорійного значення статичної ознаки. Отже, формальним втіленням категорії предметності - визначальної ознаки іменника як частини мови - $є$ відмінкова парадигма, але в ній, на відміну від парадигм часу, способу, стану дієслова та ін., семи окремих форм протиставляються не за однією ознакою (предметності), а за різними, їй підпорядкованими: діяча, об'єкта, статичної ознаки та ін. ${ }^{6}$

3 цього висновкуємо, що саме відмінку притаманна найпослідовніше виражена порівняно 3 іншими морфологічними категоріями іменника семантична спеціалізація ${ }^{7}$, у зв’язку з чим гра, маніпуляція відмінковими формами, їх транспозиція у сферу вживань опозиційних одиниць практично неможлива, оскільки складові категорії відмінка й не утворюють таких опозицій.

Підтверджують цю тезу міркування Є. Шендельс, що, досліджуючи процес нейтралізації граматичних опозицій як наслідок транспозиції одного члена категорії у сферу вживання іншого, приходить до висновку, що така нейтралізація неможлива для тих форм, що безпосередньо не протиставляються одна одній, зокрема дослідник характеризує в російській мові шестичленну й восьмичленну опозиції․

Лексичне значення іменника виступає в нерозривному зв'язку з граматичним значенням відмінка ${ }^{9}$. Сутність відмінка, як наголошують дослідники, одночасно й морфологічна, й синтаксична (зміна відмінкової форми разом із тим $\epsilon$ зміною синтаксичної функції іменника ${ }^{10}$; відмінок „впливає на семантикосинтаксичну структуру речення, чого не здійснюють категорії роду та числа" 11 ), „однак не семантична, бо лексичне значення іменника в усіх відмінках те саме”12. На це ж указує й I. Кучеренко: у кожній із відмінкових форм, у яких іменник виступає в реченні, виражаючи певне відношення названого ним (речі, предмета, особи) до інших предметів і явищ, він має одне значення - семантика його (реальне лексичне значення) не змінюється ${ }^{13}$.

Такі твердження (неможливість транспозиції для утворення ігрем за участі граматичного значення відмінка, стале лексичне значення різних відмінкових форм) спонукають до висновку про неможливість з'яви в лексичного значення слова оцінних сем, що було б мотивовано відповідною маніпуляцією граматичним значенням відмінка.

Проте можна змоделювати породження значення оцінки шляхом утворення неправильних відмінкових форм. Це можливо там, де є своєрідна варіативність й, відповідно, вибір відмінкових закінчень через наявність суміжних парадигм. Окремої уваги заслуговують випадки вживань, коли мовці, використовуючи невідмінювані іменники, починають застосовувати щодо них певну парадигму відмінювання, що „надає мовленню комічного звучання”"14. Учені наголо-

\footnotetext{
${ }^{6}$ Там само.

${ }^{7}$ I. Р. Вихованець, Система відмінків української мови, Київ 1987, 232 с.

${ }^{8}$ Е. И. Шендельс, Многозначность и синонимия в грамматике, Москва 1970, с. 15.

${ }^{9}$ I. К. Кучеренко, Категорія відмінка в сучасній украӥнській мові, Львів 1961, с. 6.

${ }^{10}$ М. В. Леонова, Зазнач. праия, с. 54.

${ }^{11}$ О. К. Безпояско, Зазнач. прачя, Київ 1993, с. 21.

${ }^{12}$ С. П. Дудик, Стилістика украӥнської мови, Київ 2005, с. 195.

${ }^{13}$ І. К. Кучеренко, Зазнач. праия, с. 9.

${ }^{14}$ И. Б. Голуб, Стилистика современного русского языка, Москва 2003, с. 237.
} 
шують, що відмінюваність слів письменники використовують як засіб художньої виразності саме тоді, коли персонажі починають відмінювати слова, порушуючи норми літературної мови. Уживання в мовленні персонажів спотворених відмінкових форм, що розглядаються як безграмотні (порівн. (рос.): местов, делов, блюдов і т. ін. $\left.{ }^{15}\right)$, цілком закономірне. Художники слова прагнуть відтворити неправильність у мовленні героїв, що віддають перевагу просторіччю, як засіб яскравої мовленнєвої характеристики людини низької культури, напр. (рос.): Подвиньтесь! Вам говорят! Дайте мадаме место! ${ }^{16}$; [Фамусов] ...Да не в мадаме сила ${ }^{17}$.

Як демонструє проаналізований фактичний матеріал, необхідно розмежовувати такі вживання: по-перше, навмисні порушення при відмінюванні іменників, що породжують відповідні ігреми для вираження іронії, оцінки (ігрема виникає як наслідок маніпуляції граматичним значенням відмінка, що змінює граматичні ознаки слова й сприяє породженню прагматичної оцінної інформації), і по-друге, що, як було зазначено, спостерігаємо зокрема в художній літературі, - негативна оцінка персонажа через його неграмотність - порушення відмінкових норм (таке порушення ігрему не сформувало, а негативно оцінюється сам мовець).

Серед інших перетворень морфологічної форми слова О. Земська на матеріалі російської мови розглядає неправильне утворення відмінкових форм, що слугує для породження жартів, порівн. (рос.): А. У него губы как у Кобзона // Б. Не знаю ни Кобзона / ни его губей ${ }^{18}$. Названа дослідниця також характеризує як найпростіший і найпоширеніший спосіб мовної гри так званий прийом мовленнєвої маски, який полягає в тому, що мовець навмисно говорить незвично, наслідуючи когось. Використовуючи цей прийом, зазвичай не турбуються про повне відтворення чужого мовлення, лише кидають окремі ,яскраві мазки”, найбільш характерні ознаки чужого голосу. Мовець досягає експресивності, намагаючись зробити своє мовлення незвичним для даної ситуації. Ефект комізму створюється контрастом між ситуацією, контекстом й ознаками чужого мовлення, що викликають уявлення про інших мовців та іншу ситуацію ${ }^{19}$. Прийом може бути використано і як характерологічний, оцінний засіб (для зображення людини), тоді він отримує смислове навантаження й переходить у сферу гострослів'я, дотепності й слугує частіше для вираження негативної оцінки. Найпоширеніші на сьогодні, як зазначає О. Земська, ігрові маски малокультурного простачка (гра на діалектах і просторіччі) та бюрократа (гра на канцеляризмах $)^{20}$. Застосування першої, як спостерігаємо, можливо й за участі граматичного значення відмінка, порівн.: - щ ще подаруємо квіти ... - O-о-о, обов'язково, багато ромашків, трояндів (з мовлення того, про кого йдеться) (з розм. мовл).

Проте у віршованому тексті бачимо, що таке ж порушення не зумовлює 3'яву додаткової конотації, оскільки використовується для дотримання законів віршобудови, напр.: Загубилася любов між нами, Як вітер серед спілих трав. Загубилася між пелюстками Трояндів, щуо їх дарував ${ }^{21}$.

15 А. И. Ефимов, Стилистика художественной речи, Москва 1961, с. 321.

16 Там само.

${ }^{17}$ И. Б. Голуб, Указан. работа, Москва 2003, с. 237.

18 Русская разговорная речь: Фонетика. Морфология. Лексика. Жест, под. ред. Е. А. Земской, Москва 1983, с. 179.

19 Там само, с. 180.

${ }^{20}$ Там само.

${ }^{21}$ Hаше: тексти пісень, [в:] Електронний ресурс: http://nashe.com.ua/song.htm?id=9185. 
Приклади підтверджують: мовці іронізують, порушуючи іменникову невідмінюваність, напр: A поїдемо куме на метрі покатаємось? ${ }^{22}$. Цей засіб українці скеровують на анекдоти, що стає яскравим засобом створення гумористичного ефекту: Украӥна. Автобус. До самотньо сидячої, смутної, утомленої жінки звертається чоловік: - Dode ра?. Все золото миру не світить яскравіше, ніж вона в июю мить! Франиуз!! Справжній ФРАНЦУЗ У ІІІ ЖИТТІ!!! Все, кінецьь сірим будням! Прощайте, украӥнські чоловіки зі своӥми хокеями, риболовлями й розкиданими носками. Тепер будуть шампанське й танго в підніжжя Ейфелевої вежі, сонще й білий морський пісок. I, зрозуміло, Шанель! Але! Але треба ж щзось відповісти! - Пардон мсьє! Кес ке се? - Автобус, питаю, до депа йде? ${ }^{23}$. Як засіб негативної оцінки в анекдоті також використано граматичне значення числа: синтаксичний фразеологізм зі значенням узагальнювальної множинності: українські чоловіки зі своӥми хокеями, риболовлями й розкиданими носками.

Цікавим є вживання словосполучення кіна не буде, що його використовують у сучасній комунікації як усталене, де одним із засобів породження оцінки $\epsilon$ змінена форма невідмінюваного іменника. Висловлювання вживають у переносному значенні, що частіше вказує на негативну оцінку певної події, що не відбулася, відмінилася й т. ін. Спостерігаємо подібні вживання в публіцистиці (часто в газетних заголовках), де подана далі інформація підтверджує вираження негативу, порівн.: Кіна не буде. Бізнес розвалився 24 ; „Кіна не буде - касета пожсована". Від провокачій Олега Ляшка втомилися навіть колеги по БЮТу ${ }^{25}$; Кіна не буде. Б'ютівська провокачія з ТВК не вдалася ${ }^{26}$; Кіна не буде - права скінчилися. Під час поӥзки на автобусі багато пасажирів мимоволі стають причетними до порушень права інтелектуальної власності ${ }^{27}$ і т. ін. Отже, як бачимо, використовуючи прецедентний негативнооцінний зміст висловлювання кіна не буде, що сформувався і за участі граматичного значення відмінка, журналісти налаштовують читача на очікування інформації негативного характеру.

Додаткового коментаря потребує вживання згаданої вище лексеми мадам, де спостерігаємо одночасне застосування кількох засобів вираження оцінки, їх аплікацію при функціюванні такого типу слів у сучасній комунікації. Досліджуючи агентивні імена морально-етичної оцінки, серед інших семантичних груп підсистеми назв особи Т. Космеда виділяє іменники-назви осіб ,за соціальним статусом чи походженням”. Як зазначає названа дослідниця, багато із слів цієї групи втратили свої основні значення, причому переносні значення витіснили основні ${ }^{28}$. Слова, вжиті в переносному значенні, вплітаючись у

${ }^{22}$ Рупор фракиции Понаехавщих, [в:] Электронный ресурс: http://www.moswar.org/main/83-apoyidemo-kume-na-metr-pokatayemos.html. (29.03.2011).

${ }^{23}$ Украӥнські анекдоти, [в:] Електронний ресурс: http://ukr-anecdotes.com/rozdil/pro-teshhu/ page/16.

${ }^{24}$ Кіна не буде. Бізнес розвалився, [в:] Електронний ресурс: http://www.vlasnasprava.info/ua/ business_az/how_to_grow/losers.html?_m=publications\&_t=rec\&id=685.

${ }_{25}$ „Кіна не буде - касета пожована”. Від провокацій Олега Ляика втомилися навіть колеги по БЮТу, [в:] Електронний ресурс: http://www.tovarish.com.ua/archive/866/vtoraia_po/Kina ne_bu.html.

${ }^{26}$ Кіна не буде. Б’ютівська провокація з ТВК не вдалася, [в:] Електронний ресурс: http://www. mukachevo.net/ua/news/view/21306-\%D0\%BA\%D1\%96\%D0\%BD\%D0\%B0-\%D0\%BD\%D0\%B5$\% \mathrm{D} 0 \% \mathrm{~B} 1 \% \mathrm{D} 1 \% 83 \% \mathrm{D} 0 \% \mathrm{~B} 4 \% \mathrm{D} 0 \% \mathrm{~B} 5$.

${ }^{27}$ Кіна не буде - права скінчилися, [в:] Електронний ресурс: http://patent.km.ua/ukr/articles/ i901 (26.06.2006)

${ }^{28}$ Т. А. Космеда, Функиионально-семасиологическое исследование имен предметно признаковой семантики, [в:] Ф. С. Бацевич, Т. А. Космеда, Очерки по функциональной лексикологии, Львов 1997, с. 251. 
смислову канву тексту, „слугують образним засобом створення сатири й гумору, ефективним прагматичним засобом, оскільки викликають у читача певну реакцію: відчуття обурення, зневаги, ненависті, співчуття, схвалення" і т. ін. ${ }^{29}$

Навмисне відмінювання невідмінюваного іменника мадам стає засобом підсилення оцінки, напр.: Кролика Сєню бачили на Золотих, з якоюсь мадамою по бутіках шаривсь — крайну рятував ${ }^{30}$; ...хахаха ...mа не з иією мадамою йому нічо не світить!!! ${ }^{1}$; А Біличка з отією мадамою-утконосом усе у кадр пнуться ${ }^{32}$; А хто ж стоїь за Юлькою? А за иүією мадамою стоять торгаші, торгамі без роду-племені, яким пофіг чим торгувати - китайським лахміттям на Барабашова, китайськими швидкими чи ,японськими” молоковозами зз.

Як наголошує I. Голуб, пояснення потребує і факт відмінювання власних назв ${ }^{34}$. Норма щодо невідмінювання деяких прізвищ існувала не завжди, в XIX ст. були можливі варіанти, відголоски чого впливають і на сучасне вживання таких іменників. У розмовному мовленні можна зустріти відмінювані форми жіночих українських прізвищ на $-\kappa o^{35}$. Такі відхилення від мовної норми можуть бути цілком виправдані прагматичними цілями комунікації - вираження незадоволення, іронії, негативної оцінки, порівн.: Я за Федірку праияювати не збираюсь (з розм. мовл.); Та від Зарудки ти нічого не доб 'єшся (з розм. мовл.); От і спитаєш Рибалку, для чого вона це робить (з розм. мовл.). 3 відповідною метою спостерігаємо спотворення навіть форми називного відмінка: Щось останнім часом Федірка дуже розумна (з розм. мовл.).

Оригінальним є те, що деякі прислівники утворюють відмінкові форми за аналогією 3 іменниками ${ }^{36}$ : Ти сюдою, я тудою, $A$ зійдемось над водою (Леся Українка); Чи не бачив парубка і дівки, чи не йшли сюдою (I. Рудченко); Ми дивимося кудою до нори ближче (I. Рудченко); Ото якось там купиі знову їхали тудою, та й до їх заїхали (І. Рудченко). У наведених контекстах такі форми не пов'язані зі зміною значення, зокрема з вираженням оцінки, проте й такий засіб може бути використано в художньому тексті для негативної характеристик героя через неправильність його мовлення.

У процесі творення оказіональних граматичних форм можливою є одночасна маніпуляція кількома граматичними засобами, порівн.: Hapoде! Bpeumі спинимось. Ставати квазімодами. Ходімо прямоспинними, Щоб завжди бути гордими ${ }^{37}$. У наведеному прикладі під час утворення відонімної множинної форми (узагальнювальна множинність - гра граматичним значенням числа) порушується ще одна граматична ознака - невідмінюваність, тобто в породженні оцінки беруть участь граматичні значення і числа, й відмінка. При вживанні наведеної вище множинної форми в конструкції „хтось (ім. чол. роду) y спідниці" 38 (напр.: ... все ж таки клопіт, а з другого боку, може й подобалось,

29 Там само, с. 252.

${ }^{30}$ Гуртомівка. 24 серпня 2010 року (Київ), [в:] Електронний ресурс: http://toloka.hurtom.com/ viewtopic.php? $\mathrm{p}=218075$.

${ }^{31}$ В контакті, [в:] Електронний ресурс: http://vkontakte.ru/id8126459.

${ }^{32}$ Альо, ми шукаєм таланти, [в:] Електронний ресурс: http://ragu.li/post/alo-my-shukajem-talanty/.

33 Про одне пророитво, [в:] Електронний ресурс: http://forum.durdom.in.ua/viewtopic. $\mathrm{php} \mathrm{f}=1 \& \mathrm{t}=53912 \& \mathrm{p}=968415$.

${ }^{34}$ И. Б. Голуб, Указан. работа, Москва 2003, с. 235.

35 Там само, с. 236.

${ }^{36}$ В. С. Ващенко, Стилістична морфологія украӥнської мови, Дніпропетровськ 1970, с. 106.

${ }^{37}$ М. Савчук, Цілюща метафора, [в:] Електронний ресурс: http://www.poetryclub.com.ua/ getpoem.php?id=207689.

${ }^{38}$ О. В. Халіман, Зазнач. праця, с. 8. 
себто подобались майбутні няньки: „Не пришле ж вона мені якихсь квазімодів у спідницях", - міркував він і помилився ${ }^{39}$ долучається й граматичне значення роду - застосування прецедентної інформації, пов’ язаної з носієм власної назви як особи чоловічої статі, щодо осіб жіночої статі.

Отже, в сучасній українській мові за кожним відмінком історично закріпилося певне категорійне значення. Своєрідність відмінка як граматичної категорії зумовлює обмеженість його участі в породженні оцінки через неможливість „сміливих” транспозицій відмінкових грамем у зв'язку з їхньою вузькою семантичною специфікою. Виникнення ігрем для вираження оцінки як вторинної функції граматичного значення відмінка можливе при цілеспрямованому утворенні неправильних відмінкових форм відмінюваних і невідмінюваних слів. Цей же засіб також може бути використано як оцінний під час створення певного образу, наприклад, у художній літературі: порушення норм утворення відмінкових форм, що не є з боку мовця цілеспрямованим і відповідних ігрем не формує, характеризує його негативно.

Перспектива дослідження - аналіз у виокремленому ракурсі інших граматичних категорій української мови для створення цілісної теорії „Граматики оцінки”.

${ }^{39}$ Т. Шевченко, Нещъасний, [в:] Електронний pecypc: http://www.ukrcenter.com/Література/ Тарас-Шевченко. 